\title{
Agronomic performance of 'Cabernet Sauvignon' with leaf removal management in a high-altitude region of Southern Brazil
}

\author{
Douglas André Würz ${ }^{(1)}$, Alberto Fontanella Brighenti(2), José Luiz Marcon Filho(3), \\ Ricardo Allebrandt( ${ }^{(1)}$, Betina Pereira de Bem ${ }^{(1)}$, Leo Rufato ${ }^{(1)}$ and Aike Anneliese Kretzschmar ${ }^{(1)}$
}

\begin{abstract}
(1)Universidade do Estado de Santa Catarina, Centro de Ciências Agrárias, Avenida Luiz de Camões, no 2.090, Conta Dinheiro, CEP 88520-000 Lages, SC, Brazil. E-mail: douglaswurz@hotmail.com, ricardoudesc@yahoo.com.br, betadebem@yahoo.com.br, leoruffato@yahoo.com.br, aikeanneliese@yahoo.com.br ${ }^{(2)}$ Empresa de Pesquisa Agropecuária e Extensão Rural de Santa Catarina, Estação Experimental de São Joaquim, Rua João Araújo Lima, no 102, Jardim Caiçara, CEP 88600-000 São Joaquim, SC, Brazil. E-mail: albertobrighenti@epagri.sc.gov.br ${ }^{(3)}$ Viticultura Vinícola Legado, Rodovia Raul Azevedo de Macedo, no 5.800, CEP 83606-482 Campo Largo, PR, Brazil. E-mail: marconfilho_jl@yahoo.com.br
\end{abstract}

Abstract - The objective of this work was to compare the effect of different times of leaf removal on the vegetative-productive efficiency and on the chemical and physical characteristics of 'Cabernet Sauvignon' clusters in a high-altitude region of the state of Santa Catarina, Brazil. The experiment was conducted in the 2015 and 2016 vintages, in a commercial vineyard, located in the municipality of São Joaquim, in the state of Santa Catarina, at 1,230-m altitude. The treatments consisted of different times leaf removal in the cluster zone, in the following phenological stages: full bloom, buckshot berries, pea-sized berries, veraison, and 15 days after veraison, besides a control without leaf removal. The evaluated variables were subjected to the analysis of variance and compared with the Scott-Knott test, at 5\% probability. In a high-altitude region, leaf removal provides more adequate indices for plant vegetative:yield balance. It also increases yield when performed during the pea-sized berry and veraison stages, increases the fertility index when performed during the pea-sized berry stage, and improves the chemical composition of 'Cabernet Sauvignon' grape when performed up to the pea-sized berry stage. The obtained results show the importance of early leaf removal to obtain must with potential for the production of quality wines.

Index terms: Vitis vinifera, altitude wines, early leaf removal, grape ripening, vine management.

\section{Desempenho agronômico de 'Cabernet Sauvignon' com manejo de desfolha em região de elevada altitude no Sul do Brasil}

\begin{abstract}
Resumo - O objetivo deste trabalho foi comparar o efeito de diferentes épocas de desfolha na eficiência vegeto-produtiva e nas características químicas e físicas dos cachos de 'Cabernet Sauvignon' em regiões de elevada altitude, em Santa Catarina. O experimento foi conduzido nas safras 2015 e 2016, em um vinhedo localizado no Munícipio de São Joaquim, SC, a $1.230 \mathrm{~m}$ de altitude. Os tratamentos consistiram em diferentes épocas de desfolha, na região dos cachos, nos seguintes estádios fenológicos: plena florada, baga chumbinho, baga ervilha, virada de cor das bagas e 15 dias após a virada de cor, além de testemunha sem desfolha. As variáveis avaliadas foram submetidas à análise de variância e comparados pelo teste de Scott-Knott, a $5 \%$ de probabilidade. Em região de altitude, a desfolha proporciona índices mais adequados de equilíbrio vegetativo:produtivo da planta. Também aumenta a produtividade quando realizada nos estádios fenológicos baga ervilha e virada de cor, aumenta o índice de fertilidade quando realizada no estádio fenológico baga ervilha e melhora a composição química da uva 'Cabernet Sauvignon' quando realizada até o estádio fenológico baga ervilha. Os resultados obtidos evidenciam a importância da desfolha precoce para obtenção de um mosto com potencial para elaboração de vinhos finos de qualidade.
\end{abstract}

Termos para indexação: Vitis vinifera, viticultura de altitude, desfolha precoce, maturação da uva, manejo da videira.

\section{Introduction}

Grapevines cultivated in highland regions of the state of Santa Catarina, Brazil $\left(26^{\circ}\right.$ and $28^{\circ} \mathrm{S}$, at altitudes between 950 and 1,400 $\mathrm{m}$ ), present longer phenological stages than those of other winegrowing areas in the country (Brighenti et al., 2013). These regions show potential to produce quality wines, mainly due to the great availability of solar radiation and low night temperatures (Malinovski et al., 2016). 
The 'Cabernet Sauvignon' (Vitis vinifera $\mathrm{L}$.) variety has the largest production area in the high-altitude regions of Santa Catarina, corresponding to $37 \%$ of the planted area (Vianna et al., 2016). However, this variety has a late and long cycle (214 days) that requires a higher thermal summation to complete its phenological stages, and its harvest happens in late April, when there are considerable drops in temperature in the region (Brighenti et al., 2013). Consequently, in cold and rainy years, there is a risk of harvesting 'Cabernet Sauvignon' with inadequate maturation parameters, such as high acidity and excess herbaceous aromas. Furthermore, the edaphoclimatic conditions of the high-altitude regions of Santa Catarina, such as high water availability (Bem et al., 2016) and high organic matter in the soil (Mafra et al., 2011), promote excessive vegetative growth. This shows that it is necessary to perform some canopy managements to improve vine balance, which allows grapes to be harvested at appropriate levels of maturity.

Vine growth management for wine grape cultivation has aimed to optimize sunlight interception, photosynthetic capacity, and canopy microclimate in order to improve fruit production and wine quality, especially for vigorous varieties with dense canopies (Jogaiah et al., 2013).

Basal leaf removal may be employed to improve air and light exposure around clusters, as well as to open access to disease- and pest-control chemicals (Miele \& Mandelli, 2012). This vineyard practice is carried out in all wine-growing regions, usually between the setting and veraison phenological stages of the grapevine (Diago et al., 2010), although it has become more common before setting (Komm \& Moyer, 2015). An effect generally associated with basal leaf removal is the reduction in the incidence of bunch rot (Molitor et al., 2011). Besides, the removal of basal leaves may also significantly enhance anthocyanin levels and skin color, particularly in cool climates (Lee \& Skinkis, 2013; Sternad Lemut et al., 2013); increase sugar and polyphenols, improving grape quality at harvest (Poni et al., 2006); and cause a drop in titratable acidity (Poni et al., 2006; Diago et al., 2012).

The objective of this work was to compare the effect of different times of leaf removal on the vegetativeproductive efficiency and on the chemical and physical characteristics of 'Cabernet Sauvignon' clusters in a high-altitude region of the state of Santa Catarina, Brazil.

\section{Materials and Methods}

The experiment was performed in a commercial vineyard, planted with the variety 'Cabernet Sauvignon', located in the municipality of São Joaquim ( $28^{\circ} 17^{\prime} 39^{\prime \prime} \mathrm{S}, 49^{\circ} 55^{\prime} 56^{\prime \prime} \mathrm{W}$, at $1,230 \mathrm{~m}$ of altitude), in the state of Santa Catarina, Southern Brazil, during the 2015 and 2016 vintages. The experimental design was randomized complete blocks with four blocks and five plants per plot.

The climate of the region has been classified as "cool, cool nights, and humid", with heliothermic index of 1,714, average annual rainfall of 1,621 $\mathrm{mm}$, and annual average relative humidity of $80 \%$ (Tonietto \& Carbonneau, 2004). Daily rainfall, relative humidity, and mean temperatures were recorded at an automatic weather station located near the vineyard, in the municipality of São Joaquim, in the state of Santa Catarina. Data were provided by Centro de Informações de Recursos Ambientais e de Hidrometeorologia de Santa Catarina (Figure 1). The meteorological variables were collected between November and April of 2014/2015 and 2015/2016, periods that coincide with full bloom and harvest, respectively. The soil is a Cambissolo (Inceptisol), which is characterized as having high clay $\left(492 \mathrm{~g} \mathrm{~kg}^{-1}\right)$ and organic matter $(71 \mathrm{~g}$ $\mathrm{kg}^{-1}$ ) contents (Solos..., 2004).

'Cabernet Sauvignon' vines (grafted on '1103 Paulsen') were planted in 2004 in a northwest to southeast row orientation, with a $3.0 \mathrm{~m}$ (row) x $1.5 \mathrm{~m}$ (vine) spacing. Vines were trained on a vertical shoot position with double-cordon and spur pruning at 1.2-m height and were covered with an anti-hail net.

The treatments consisted of leafremoval at the cluster zone in five different phenological stages according to the Baillod \& Baggiolini (1993) scale: full bloom, buckshot berries, pea-sized berries, veraison, and 15 days after veraison, besides a control without leaf removal. Leaves were removed manually by removing three basal leaves, including the leaf opposite to the cluster, exposing the grapes completely. Vineyard practices (pruning, shoot topping, and disease control) were maintained as recommended to commercial growers in the region.

Harvest started on 4/1/2015 and 3/17/2016 according to the winery standards. During harvest, the number of clusters, shoots per vine, and production $(\mathrm{kg}$ per vine) were determined for eight plants per treatment. 
Based on these data, yield $\left(\mathrm{Mg} \mathrm{ha}^{-1}\right)$ and bud fertility (clusters per shoot) were estimated.

At harvest, 150 berries were randomly collected per plot/treatment from different portions of the clusters and both sides of the rows. Samples were immediately subjected to the analyses of soluble solids, total acidity, and $\mathrm{pH}$, following the protocols of International Organisation of Vine and Wine (OIV, 2015). From the grape must, the soluble solids content was determined in a digital temperature-compensated refractometer

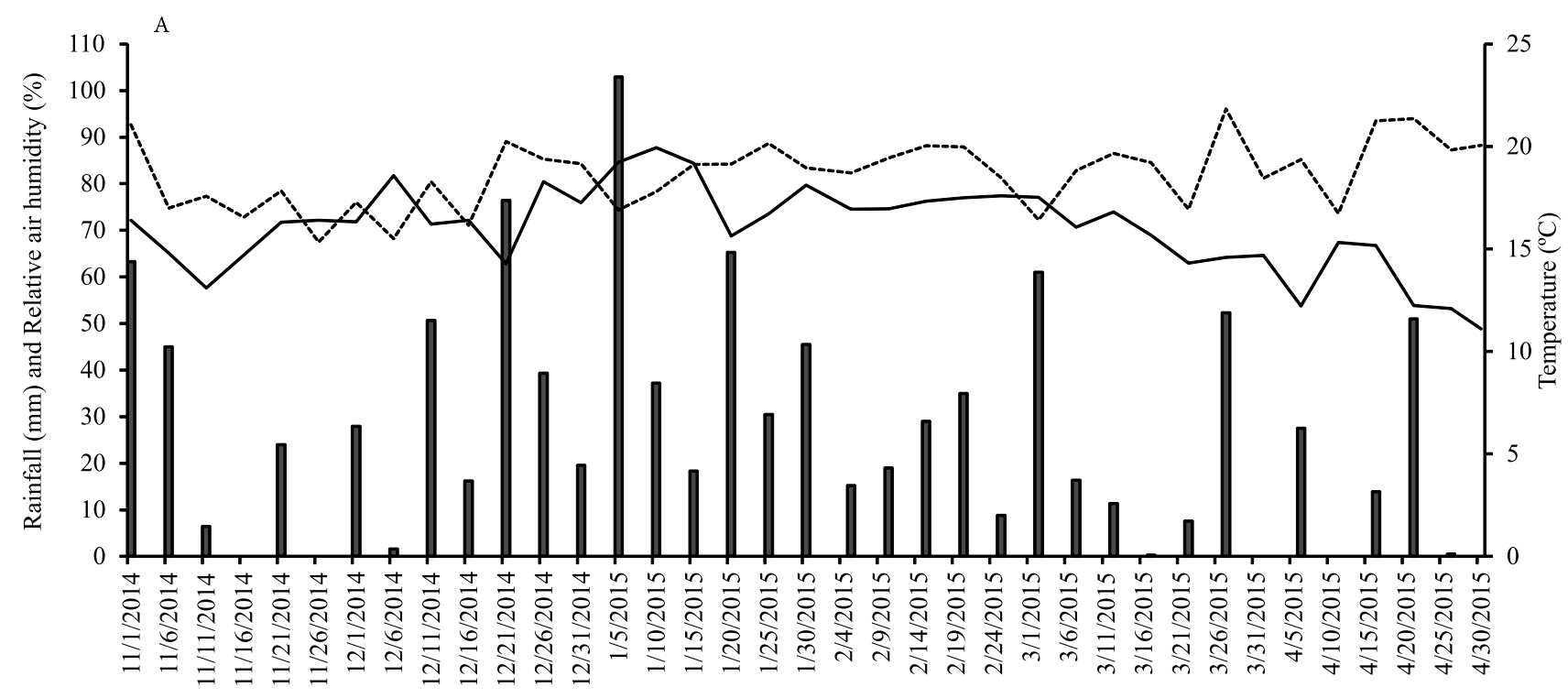

Data

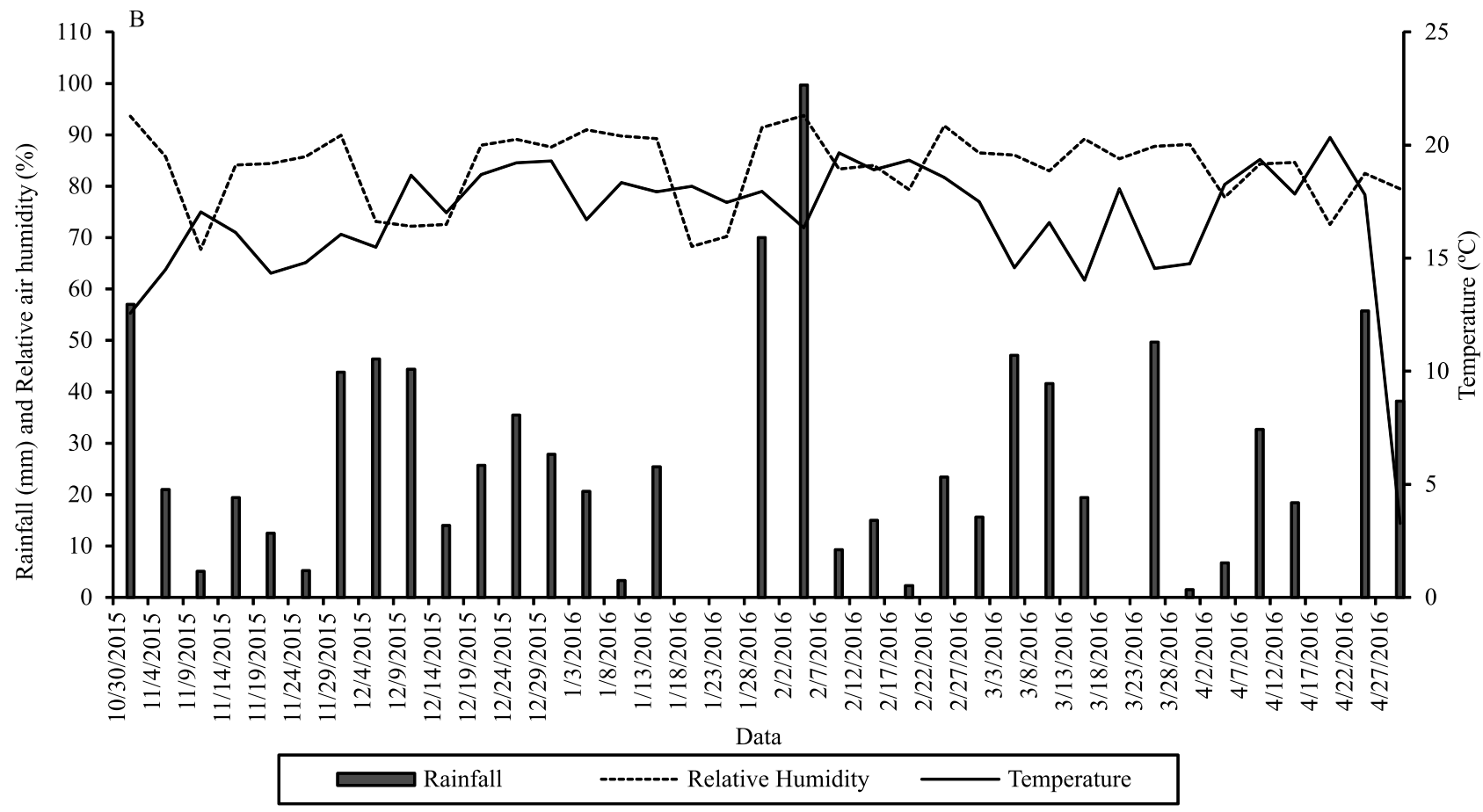

Figure 1. Cumulative rainfall $(\mathrm{mm})$, relative air humidity $(\%)$, and mean air temperature $\left({ }^{\circ} \mathrm{C}\right)$ in the municipality of São Joaquim, in the state of Santa Catarina, Brazil, during the 2015 (A) and 2016 (B) vintages of 'Cabernet Sauvignon' (Vitis vinifera). 
(ITREFD 45 model, Instrutemp - Instrumentos de Medição, São Paulo, SP, Brazil), with results expressed in ${ }^{\circ}$ Brix; total acidity was obtained by titration with 0.1 $\mathrm{N} \mathrm{NaOH}$ until the $\mathrm{pH}$ of the medium reached 8.2, with results expressed as meq $\mathrm{L}^{-1}$; and $\mathrm{pH}$ was measured with a potentiometer (Impac Comercial e Tecnologia Ltda., São Paulo, SP, Brazil).

From grape skins, the contents of total polyphenols and anthocyanins were evaluated at both vintages. For polyphenol extraction, $25 \mathrm{~g}$ skins were weighted, homogenized in $10 \mathrm{~mL}$ methanol (1:1), macerated for 24 hours at $30 \pm 0.5^{\circ} \mathrm{C}$, and then washed with 2.5 $\mathrm{mL}$ methanol (1:1). A second extraction from the remains of the skins was performed using the same methanol volume and time, at $0 \pm 0.5^{\circ} \mathrm{C}$. Both extracts were separated, homogenized, and filtered through Whatman 01 filter paper (Marcon Filho et al., 2015). Total polyphenol content was determined by the spectrophotometry method described by Singleton \& Rossi (1965), using the Folin-Ciocalteu reagent, with absorbance in $760 \mathrm{~nm}$ wavelength. Phenolic content was obtained using a gallic acid calibration curve, whereas total anthocyanins were determined by the spectrophotometry method according to RibéreauGayon et al. (1998).

Leaf area $\left(\mathrm{m}^{2}\right.$ per vine) was estimated during harvest from the correlation between the central vein length and area of an individual leaf (Borghezan et al., 2010). The leaf area measurements were made on 10 shoots. The following equation was obtained: $\mathrm{y}=1.1265 \mathrm{x}^{2.0445}$, in which y corresponds to the leaf area to be estimated $\left(\mathrm{cm}^{2}\right)$ and $\mathrm{x}$ corresponds to the central vein length of the leaf $(\mathrm{cm})$. Based on these data, the vine balance:leaf area/yield $\left(\mathrm{cm}^{2} \mathrm{~g}^{-1}\right)$ and yield/leaf area $\left(\mathrm{kg} \mathrm{m}^{-2}\right)$ ratios were obtained.

The data were subjected to the analysis of variance, at $5 \%$ probability, and, when treatment effects were detected, the Scott-Knott test was performed, also at $5 \%$ probability.

\section{Results and Discussion}

Regarding the number of clusters per plant, no differences were observed in the 2015 vintage. However, in 2016, plants subjected to leaf removal during the pea-sized berry and veraison stages presented a higher number of clusters than those subjected to the other treatments. This result is related to the fertility index (number of clusters per shoot), which was higher in plants defoliated at pea-sized berries and veraison (Table 1). In 2016, when the plants were not subjected to leaf removal (control) or when leaves were removed 15 days after veraison, there was a reduction in bud fertility, caused by excessive shading in the region of clusters and buds. The formation of a fertile bud is a consequence of the differentiation of an undifferentiated primordium into a reproductive primordium (Botelho et al., 2006), and light intensity is the most limiting factor for the formation of fertile buds. Unsatisfactory light conditions during inflorescence initiation severely reduce bud fertility, and shoots more exposed to light are usually more fertile (Keller \& Koblet, 1995). Therefore, leaf removal in the cluster region exposes the buds to the sun (Tardaguila et al., 2010), affecting bud fertility and, consequently, contributing to an increase in the number of clusters per shoot.

However, these climatic conditions do not occur in the high-altitude regions of the state of Santa Catarina. Similar values for mean temperature, relative air humidity, and rainfall were observed during the experimental period from November to April (Figure 1). The 2014/2015 vintage presented averages of $16^{\circ} \mathrm{C}, 82.1 \%$, and $1,019 \mathrm{~mm}$, respectively, while the $2015 / 2016$ vintage had averages of $16.8^{\circ} \mathrm{C}, 83.6 \%$, and $953.4 \mathrm{~mm}$. Therefore, bud exposure through leaf removal is an alternative to increase temperature and to obtain direct solar radiation in the bud region, improving floral differentiation.

Plants defoliated during veraison presented higher yields, followed by those defoliated during the pea-sized berry stage (Table 1). These results coincide with higher values of the bud fertility index. When leaf removal was carried out in the full bloom stage, that is, earlier than in traditional timings of defoliation, there was a reduction in yield, because the removal of basal leaves reduces the availability of carbohydrates; therefore, the fruit set is poorer and the clusters are smaller (Poni et al., 2006; Tardaguila et al., 2010).

Regarding the technological maturity of 'Cabernet Sauvignon', no difference was observed for soluble solids in the 2015 vintage; however, in 2016, early leaf removal at full bloom, buckshot berries, and peasized berries resulted in the highest soluble solids values (Table 2). Intrieri et al. (2008) and Gatti et al. (2012) found similar results, which may be related to increased sun exposure in the cluster zone. 
In the 2015 vintage, leaf removal in the buckshot berry, pea-sized berry, and veraison phenological stages resulted in lower values of total acidity; however, in 2016, only leaf removal performed at pea-sized berries resulted in a reduction of 'Cabernet Sauvignon' total acidity. Early leaf removal, associated with a high incidence of solar radiation, provides a reduction in total acidity contents, due to the degradation of malic acid (Intrigliolo et al., 2014; Risco et al., 2014). This effect may also be a result of the direct exposure of clusters to the sun, which increases their temperature and, consequently, the rate of cellular respiration, causing malic acid degradation (Conde et al., 2007).

In the 2015 vintage, the $\mathrm{pH}$ values were below 3.30 for all timings of leaf removal, but were significantly lower in plants defoliated during full bloom and in those that were not defoliated (control). In the 2016 vintage, no differences were observed between the different timings of leaf removal in the $\mathrm{pH}$ of 'Cabernet Sauvignon' (Table 2). Other studies also reported little or no effect of leaf removal in the $\mathrm{pH}$ of grape (Scheiner et al., 2010; Mosetti et al., 2016).
In general, for the production of quality red wines, the recommended must characteristics are soluble solids contents above $20^{\circ} \mathrm{Brix}$, total acidity lower than $135 \mathrm{meq} \mathrm{L}^{-1}$, and $\mathrm{pH}$ lower than 3.5 (Jackson, 2014). Early leaf removal until veraison enables reaching near-ideal maturity indexes. Poni et al. (2006), in a previous research, concluded that early leaf removal, performed before veraison, has a beneficial effect on grape quality, increasing soluble solids and reducing total acidity. Moreover, early leaf removal exposes berries to higher temperatures and to a higher incidence of solar radiation, resulting in a decrease in total acidity and in increases in $\mathrm{pH}$, by degradation of malic acid (Intrigliolo et al., 2014).

It was verified that, in the 2015 vintage, leaf removal during the buckshot berry, pea-sized berry, and veraison phenological stages resulted in appropriate levels of total acidity and $\mathrm{pH}$ for the production of quality wines. However, in the 2016 vintage, indices considered ideal were not reached in all timings of leaf removal, although plants defoliated at buckshot berries, pea-sized berries, and veraison produced grapes with

Table 1. Effect of leaf removal timing on productive variables of 'Cabernet Sauvignon' (Vitis vinifera) in a high-altitude region of the state of Santa Catarina, Brazil, in the 2015 and 2016 vintages $^{(1)}$.

\begin{tabular}{|c|c|c|c|c|c|c|}
\hline \multirow[t]{2}{*}{ Timing of leaf removal } & \multicolumn{2}{|c|}{ Number of clusters (clusters per plant) } & \multicolumn{2}{|c|}{ Yield $\left(\mathrm{Mg} \mathrm{ha}^{-1}\right)$} & \multicolumn{2}{|c|}{ Fertility index (clusters per shoot) } \\
\hline & 2015 & 2016 & 2015 & 2016 & 2015 & 2016 \\
\hline Full bloom & $26^{\mathrm{ns}}$ & $18 \mathrm{a}$ & $2.4 \mathrm{a}$ & $2.6 \mathrm{a}$ & $0.82^{\mathrm{ns}}$ & $0.77 \mathrm{~b}$ \\
\hline Buckshot berries & 28 & $22 \mathrm{a}$ & $3.0 \mathrm{~b}$ & $4.2 b$ & 0.87 & $0.72 b$ \\
\hline Pea-sized berries & 30 & $28 \mathrm{~b}$ & $3.7 \mathrm{c}$ & $4.9 \mathrm{c}$ & 0.90 & $1.10 \mathrm{~d}$ \\
\hline Veraison & 31 & $33 b$ & $5.0 \mathrm{~d}$ & $5.6 \mathrm{c}$ & 1.00 & $0.90 \mathrm{c}$ \\
\hline 15 days after veraison & 27 & $22 \mathrm{a}$ & $3.0 \mathrm{~b}$ & $3.2 \mathrm{a}$ & 0.75 & $0.60 \mathrm{a}$ \\
\hline Control without leaf removal & 30 & $19 \mathrm{a}$ & $3.4 \mathrm{c}$ & $2.9 \mathrm{a}$ & 0.87 & $0.61 \mathrm{a}$ \\
\hline Coefficient of variation (\%) & 11.3 & 12.5 & 10.7 & 12.7 & 9.8 & 9.2 \\
\hline
\end{tabular}

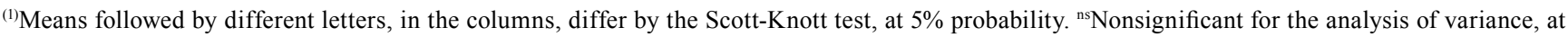
$5 \%$ probability.

Table 2. Effect of leaf removal timing on the technological maturity of 'Cabernet Sauvignon' (Vitis vinifera) in a highaltitude region of the state of Santa Catarina, Brazil, in the 2015 and 2016 vintages ${ }^{(1)}$.

\begin{tabular}{|c|c|c|c|c|c|c|}
\hline \multirow[t]{2}{*}{ Timing of leaf removal } & \multicolumn{2}{|c|}{ Soluble solids $\left({ }^{\circ}\right.$ Brix $)$} & \multicolumn{2}{|c|}{ Total acidity $\left(\mathrm{meq} \mathrm{L}^{-1}\right)$} & \multicolumn{2}{|c|}{$\mathrm{pH}$} \\
\hline & 2015 & 2016 & 2015 & 2016 & 2015 & 2016 \\
\hline Full bloom & $19.7^{\mathrm{ns}}$ & $19.1 \mathrm{~b}$ & $133.8 \mathrm{~b}$ & $163.1 \mathrm{~b}$ & $3.12 \mathrm{a}$ & $3.07^{\text {ns }}$ \\
\hline Buckshot berries & 20.4 & $19.2 \mathrm{~b}$ & $118.3 \mathrm{a}$ & $165.7 b$ & $3.17 \mathrm{~b}$ & 3.07 \\
\hline Pea-sized berries & 20.2 & $19.6 \mathrm{~b}$ & $119.7 \mathrm{a}$ & $157.8 \mathrm{a}$ & $3.20 \mathrm{~b}$ & 3.07 \\
\hline Veraison & 20.3 & $18.8 \mathrm{a}$ & $124.2 \mathrm{a}$ & $162.4 \mathrm{~b}$ & $3.20 \mathrm{~b}$ & 3.07 \\
\hline 15 days after veraison & 20.4 & $18.9 \mathrm{a}$ & $131.3 b$ & $170.9 \mathrm{~b}$ & $3.17 \mathrm{~b}$ & 3.06 \\
\hline Control without leaf removal & 19.5 & $18.6 \mathrm{a}$ & $136.4 \mathrm{~b}$ & $169.4 b$ & $3.13 \mathrm{a}$ & 3.04 \\
\hline Coefficient of variation (\%) & 2.6 & 1.7 & 4.6 & 7.6 & 0.8 & 1.4 \\
\hline
\end{tabular}


maturity indices closer to the ideal. It should be noted that, at the end of the 2016 vintage, there was a high number of rainy days and high humidity (Figure 1), and it was necessary to anticipate grape harvest.

There was no effect of leaf removal on total polyphenol content in the 2015 vintage; however, in 2016, leaf removal at buckshot berries and pea-sized berries resulted in a higher content of total polyphenols. It should be highlighted that a good-quality red grape contains a large amount of phenolic compounds. In this sense, defoliation has been an important canopy management to improve the quantity and quality of the phenolic compounds of berries (Moreno et al., 2014), and the timing of leaf removal is another key factor in the accumulation of phenolic compounds (Gatti et al., 2012). In previous studies, Moreno et al. (2014) also observed that leaf removal resulted in greater accumulation of phenolic compounds, whereas Tardaguila et al. (2010) and Risco et al. (2014) found that early leaf removal caused an increase in polyphenol content. It has been suggested that the biosynthesis of polyphenols is light dependent, favoring their accumulation (Sun et al., 2012).

For anthocyanins, the highest values were found when leaves were removed in the buckshot berry phenological stage, in the 2015 vintage, and in the buckshot berry, pea-sized berry, and veraison stages in the 2016 vintage, showing the effect of early leaf removal on the greater accumulation of anthocyanins in 'Cabernet Sauvignon' berries (Table 3). These data are in agreement with those of Di Profio et al. (2011), when studying the Cabernet Sauvignon, Merlot, and Cabernet Franc cultivars in the USA. These results can be explained by the fact that anthocyanin content is highly dependent on the levels of solar radiation, both in the vegetative canopy and directly in the clusters (Sun et al., 2012).

The best indices of vegetative balance (greater yield/ leaf area ratio and lower leaf area/yield ratio) were verified when leaf removal was carried out in the peasized berry and veraison stages. The greater vegetativeproductive imbalance occurred in plants that were not defoliated and in those defoliated during full bloom (Table 4). This is attributed to the reduction in leaf area caused by the leaf removal management, concomitantly with the higher yields observed in plants defoliated during the pea-sized berry and veraison stages.

In high-altitude vineyards, ideal leaf area/yield ratios were established as $23 \mathrm{~cm}^{2} \mathrm{~g}^{-1}$ for 'Merlot' (Borghezan et al., 2011) and $24.5 \mathrm{~cm}^{2} \mathrm{~g}^{-1}$ for 'Malbech'

Table 3. Effect of leaf removal timing on the phenolic maturity of 'Cabernet Sauvignon' (Vitis vinifera) in a highaltitude region of the state of Santa Catarina, Brazil, in the 2015 and 2016 vintages ${ }^{(1)}$.

\begin{tabular}{lccccc}
\hline Timing of leaf removal & \multicolumn{2}{c}{$\begin{array}{c}\text { Total polyphenols } \\
\left(\mathrm{mg} \mathrm{L} \text { gallic }^{-1} \text { acid }\right)\end{array}$} & & \multicolumn{2}{c}{$\begin{array}{c}\text { Anthocyanins } \\
\left(\mathrm{mg} \mathrm{L}^{-1}\right)\end{array}$} \\
\cline { 2 - 3 } \cline { 5 - 6 } & 2015 & 2016 & & 2015 & 2016 \\
\hline Full bloom & $2247.8^{\mathrm{ns}}$ & $2082.2 \mathrm{a}$ & & $154.8 \mathrm{a}$ & $198.1 \mathrm{a}$ \\
Buckshot berries & 2537.5 & $2931.4 \mathrm{~d}$ & & $181.7 \mathrm{~b}$ & $234.9 \mathrm{~b}$ \\
Pea-sized berries & 2516.5 & $2532.2 \mathrm{c}$ & & $153.6 \mathrm{a}$ & $237.0 \mathrm{~b}$ \\
Veraison & 2411.3 & $2286.4 \mathrm{~b}$ & & $162.4 \mathrm{a}$ & $236.4 \mathrm{~b}$ \\
15 days after veraison & 2305.1 & $2260.3 \mathrm{~b}$ & & $161.9 \mathrm{a}$ & $174.8 \mathrm{a}$ \\
Control without leaf removal & 2084.4 & $1902.3 \mathrm{a}$ & & $153.1 \mathrm{a}$ & $167.3 \mathrm{a}$ \\
\hline Coefficient of variation (\%) & 8.3 & 7.8 & 6.7 & 8.9 \\
\hline
\end{tabular}

(1) Means followed by different letters, in the columns, differ by the Scott-

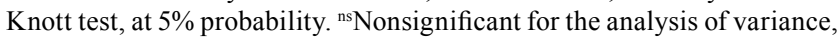
at $5 \%$ probability.

Table 4. Effect of leaf removal timing on the vegetative balance of 'Cabernet Sauvignon' (Vitis vinifera) in a high-altitude region of the state of Santa Catarina, Brazil, in the 2015 and 2016 vintages ${ }^{(1)}$.

\begin{tabular}{|c|c|c|c|c|c|c|}
\hline \multirow[t]{2}{*}{ Timing of leaf removal } & \multicolumn{2}{|c|}{$\begin{array}{l}\text { Leaf area } \\
\left(\mathrm{cm}^{2}\right)\end{array}$} & \multicolumn{2}{|c|}{$\begin{array}{c}\text { Yield/leaf area } \\
\left(\mathrm{kg} \mathrm{m}^{-2}\right)\end{array}$} & \multicolumn{2}{|c|}{$\begin{array}{c}\text { Leaf area/yield } \\
\left(\mathrm{cm}^{2} \mathrm{~g}^{-1}\right)\end{array}$} \\
\hline & 2015 & 2016 & 2015 & 2016 & 2015 & 2016 \\
\hline Full bloom & $5.1 \mathrm{a}$ & $5.2 \mathrm{a}$ & $0.21 \mathrm{~b}$ & $0.23 b$ & $47.2 \mathrm{~b}$ & $43.0 \mathrm{~b}$ \\
\hline Buckshot berries & $5.8 \mathrm{~b}$ & $5.4 \mathrm{a}$ & $0.23 b$ & $0.35 \mathrm{c}$ & $43.6 \mathrm{~b}$ & $28.6 \mathrm{a}$ \\
\hline Pea-sized berries & $7.1 \mathrm{c}$ & $6.4 \mathrm{~b}$ & $0.23 b$ & $0.35 \mathrm{~d}$ & $42.2 \mathrm{~b}$ & $29.3 \mathrm{a}$ \\
\hline Veraison & $5.8 \mathrm{~b}$ & $6.5 b$ & $0.39 \mathrm{c}$ & $0.39 \mathrm{~d}$ & $25.9 \mathrm{a}$ & $26.0 \mathrm{a}$ \\
\hline 15 days after veraison & $7.8 \mathrm{~d}$ & $7.4 \mathrm{c}$ & $0.17 \mathrm{a}$ & $0.19 \mathrm{~d}$ & $56.5 \mathrm{c}$ & $52.7 \mathrm{c}$ \\
\hline Control without leaf removal & $9.6 \mathrm{e}$ & $9.4 \mathrm{~d}$ & $0.16 \mathrm{a}$ & $0.14 \mathrm{a}$ & $61.3 \mathrm{c}$ & $71.5 \mathrm{~d}$ \\
\hline Coefficient of variation (\%) & 6.3 & 6.5 & 12.7 & 12.5 & 10.5 & 11.9 \\
\hline
\end{tabular}

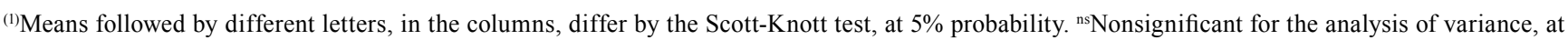
$5 \%$ probability. 
(Silva et al., 2008). Therefore, leaves removed in the pea-sized berry and veraison stages resulted in values closer to the ideal. Poni et al. (2006) reported similar results in Italy, when managing leaf removal, aiming to improve the vegetative balance of 'Sangiovese'.

The results found in the present work show that early leaf removal, performed before veraison, presented the expected benefits to the winegrower, considering the significant increase in grape quality for the production of high-quality wines. This shows that vine leaf removal is a practice that must be current in viticulture; however, it is necessary to take into account the timing and the intensity of defoliation, environmental conditions, and the variety used in order to obtain the desired benefits.

\section{Conclusions}

1. The yield of 'Cabernet Sauvignon' (Vitis vinifera) is superior when leaves are removed during the peasized berry and veraison phenological stages; however, during full bloom, yield is reduced.

2. Leaf removal reduces leaf area and, consequently, provides a better leaf area/yield ratio, which favors the ripening of 'Cabernet Sauvignon' grapes in a highaltitude region.

3. Early leaf removal, performed before veraison, results in values of $\mathrm{pH}$, soluble solids, and total acidity that are adequate for the production of high-quality wines.

\section{Acknowledgments}

To Coordenação de Aperfeiçoamento de Pessoal de Nível Superior (Capes), for scholarship granted.

\section{References}

BAILLOD, M.; BAGGIOLINI, M. Les stades repères de la vigne. Revue Suisse de Viticulture Arboriculture Horticulture, v.25, p.7-9, 1993.

BEM, B.P. de; BOGO, A.; EVERHART, S.E.; CASA, R.T.; GONÇALVES, M.J.; MARCON FILHO, J.L.; RUFATO, L.; SILVA, F.N. da; ALLEBRANDT, R.; CUNHA, I.C. da. Effect of four training systems on the temporal dynamics of downy mildew in two grapevine cultivars in southern Brazil. Tropical Plant Pathology, v.41, p.370-379, 2016. DOI: 10.1007/s40858-016-0110-8.

BORGHEZAN, M.; GAVIOLI, O.; PIT, F.A.; SILVA, A.L. da. Comportamento vegetativo e produtivo da videira e composição da uva em São Joaquim, Santa Catarina. Pesquisa Agropecuária
Brasileira, v.46, p.398-405, 2011. DOI: 10.1590/S0100204X2011000400009.

BORGHEZAN, M.; GAVIOLI, O.; PIT, F.A.; SILVA, A.L. da. Modelos matemáticos para a estimativa da área foliar de variedades de videira à campo (Vitis vinifera L.). Ciência e Técnica Vitivinícola, v.25, p.1-7, 2010.

BOTELHO, R.V.; PIRES, E.J.P.; TERRA, M.M. Fertilidade de gemas em videiras: fisiologia e fatores envolvidos. Ambiência, v.2, p.129-144, 2006.

BRIGHENTI, A.F.; BRIGHENTI, E.; BONIN, V.; RUFATO, L. Caracterização fenológica e exigência térmica de diferentes variedades de uvas viníferas em São Joaquim, Santa Catarina - Brasil. Ciência Rural, v.43, p.1162-1167, 2013. DOI: 10.1590/ S0103-84782013005000082.

CONDE, C.; SILVA, P.; FONTES, N.; DIAS, A.C.P.; TAVARES, R.M.; SOUSA, M.J.; AGASSE, A.; DELROT, S.; GERÓS, H. Biochemical changes throughout grape berry development and fruit and wine quality. Food, v.1, p.1-22, 2007.

DI PROFIO, F.; REYNOLDS, A.G.; KASIMOS, A. Canopy management and enzyme impacts on Merlot, Cabernet franc, and Cabernet Sauvignon. II. Wine composition and quality. American Journal of Enology and Viticulture, v.62, p.152-168, 2011. DOI: 10.5344/ajev.2010.10035.

DIAGO, M.P.; AYESTARÁN, B.; GUADALUPE, Z.; GARRIDO, A.; TARDAGUILA, J. Phenolic composition of Tempranillo wines following early defoliation of the vines. Journal of the Science of Food and Agriculture, v.92, p.925-934, 2012. DOI: 10.1002/jsfa.4671.

DIAGO, M.P.; VILANOVA, M.; TARDAGUILA, J. Effects of timing of manual and mechanical early defoliation on the aroma of Vitis vinifera L. Tempranillo wine. American Journal of Enology and Viticulture, v.61, p.382-391, 2010.

GATTI, M.; BERNIZZONI, F.; CIVARDI, S.; PONI, S. Effects of cluster thinning and preflowering leaf removal on growth and grape composition in cv. Sangiovese. American Journal of Enology and Viticulture, v.63, p.325-332, 2012. DOI: 10.5344/ ajev.2012.11118.

KELLER, M.; KOBLET, W. Dry matter and leaf area partitioning, bud fertility and second season growth of Vitis vinifera L.: responses to nitrogen supply and limiting irradiance. Vitis, v.34, p.77-83, 1995.

INTRIERI, C.; FILIPPETTI, I.; ALLEGRO, G.; CENTINARI, M.; PONI, S. Early defoliation (hand vs mechanical) for improved crop control and grape composition in Sangiovese (Vitis vinifera L.). Australian Journal of Grape and Wine Research, v.14, p.25-32, 2008. DOI: 10.1111/j.1755-0238.2008.00004.x.

INTRIGLIOLO, D.S.; LLACER, E.; REVERT, J.; ESTEVE, M.D.; CLIMENT, M.D.; PALAU, D.; GÓMEZ, I. Early defoliation reduces cluster compactness and improves grape composition in Mandó, an autochthonous cultivar of Vitis vinifera from southeastern Spain. Scientia Horticulturae, v.167, p.71-75, 2014. DOI: 10.1016/j.scienta.2013.12.036.

JACKSON, R.S. Wine science: principles and applications. $4^{\text {th }}$ ed. Amsterdam: Elsevier, 2014. 978p.

Pesq. agropec. bras., Brasília, v.52, n.10, p.869-876, out. 2017 DOI: $10.1590 / \mathrm{S} 0100-204 X 2017001000006$ 
JOGAIAH, S.; OULKAR, D.P.; VIJAPURE, A.N.; MASKE, S.R.; SHARMA, A.K.; SOMKUWAR, R.G. Influence of canopy management practices on fruit composition of wine grape cultivars grown in semi-arid tropical region of India. African Journal of Agricultural Research, v.8, p.3462-3472, 2013. DOI: 10.5897/AJAR2013.7307.

KOMM, B.L.; MOYER, M.M. Effect of early fruit-zone leaf removal on canopy development and fruit quality in Riesling and Sauvignon Blanc. American Journal of Enology and Viticulture, v.66, p.424-434, 2015. DOI: 10.5344/ajev.2015.15007.

LEE, J.; SKINKIS, P.A. Oregon 'Pinot Noir' grape anthocyanin enhancement by early leaf removal. Food Chemistry, v.139, p.893-901, 2013. DOI: 10.1016/j.foodchem.2013.02.022.

MAFRA, M.S.H.M.; CASSOL, P.C.; MIQUELLUTI, D.J.; ERNANI, P.R.; GATIBONI, L.C.; FERREIRA, E.Z.; BARROS, M. de; ZAFAMENA, J.; GROHSKOPF, M.A. Atributos químicos do solo e estado nutricional de videira Cabernet Sauvignon (Vitis vinifera L.) na Serra Catarinense. Revista de Ciências Agroveterinárias, v.10, p.44-53, 2011.

MALINOVSKI, L.I.; BRIGHENTI, A.F.; BORGHEZAN, M.; GUERRA, M.P.; SILVA, A.L.; PORRO, D.; STEFANINI, M.; VIEIRA, H.J. Viticultural performance of Italian grapevines in high altitude regions of Santa Catarina State, Brazil. Acta Horticulturae, v.1115, p.203-210, 2016. DOI: 10.17660/ ActaHortic.2016.1115.30.

MARCON FILHO, J.L.; HIPÓLITO, J.S.; MACEDO, T.A.; KRETZSCHMAR, A.A.; RUFATO, L. Raleio de cachos sobre o potencial enológico da uva 'Cabernet Franc' em duas safras. Ciência Rural, v.45, p.2150-2156, 2015. DOI: 10.1590/0103$8478 \mathrm{cr} 20140995$.

MIELE, A.; MANDELLI, F. Manejo do dossel vegetativo e seu efeito nos componentes de produção da videira Merlot. Revista Brasileira de Fruticultura, v.34, p.964-973, 2012. DOI: 10.1590/ S0100-29452012000400002.

MOLITOR, D.; BEHR, M.; FISCHER, S.; HOFFMANN, L.; EVERS, D. Timing of cluster-zone leaf removal and its impact on canopy morphology, cluster structure and bunch rot susceptibility of grapes. Journal International des Sciences de la Vigne et du Vin, v.45, p.149-159, 2011. DOI: 10.20870/oenoone.2011.45.3.1495.

MORENO, D.; VILANOVA, M.; GAMERO, E.; INTRIGLIOLO, D.S.; TALAVERANO, M.I.; URIARTE, D.; VALDÉS, M.E. Effects of preflowering leaf removal on phenolic composition of Tempranillo in the semiarid terroir of western Spain. American Journal of Enology and Viticulture, v.66, p.204-2011, 2014. DOI: 10.5344/ajev.2014.14087.

MOSETTI, D.; HERRERA, J.C.; SABBATINI, P.; GREEN, A.; ALBERTI, G.; PETERLUNGER, E.; LISJAK, K.; CASTELLARIN, S.D. Impact of leaf removal after berry set on fruit composition and bunch rot in 'Sauvignon Blanc'. Vitis, v.55, p.57-64, 2016. DOI: 10.5073/vitis.2016.55.57-64.
OIV. International Organisation of Vine and Wine. Compendium of international methods of wine and must analysis. Paris: OIV, 2015. 2 v.

PONI, S.; CASALINI, L.; BERNIZZONI, F.; CIVARDI, S.; INTRIERI, C. Effects of early defoliation on shoot photosynthesis, yield components, and grape composition. American Journal of Enology and Viticulture, v.57, p.397-407, 2006.

RIBÉREAU-GAYON, P.; DUBORDIEU, D.; DONÈCHE, B.; LONVAUD, A. Traité d'oenologie: microbiologie du vin: vinifications. Paris: Dunod, 1998. v.1, 185p.

RISCO, D.; PÉREZ, D.; YEVES, A.; CASTEL, J.R.; INTRIGLIOLO, D.S. Early defoliation in a temperate warm and semi-arid Tempranillo vineyard: vine performance and grape composition. Australian Journal of Grape and Wine Research, v.20, p.111-122, 2014. DOI: 10.1111/ajgw.12049.

SCHEINER, J.J.; SACKS, G.L.; PAN, B.; ENNAHLI, S.; TARLTON, L.; WISE, A.; LERCH, S.D.; VANDEN HEUVEL, J.E. Impact of severity and timing of basal leaf removal on 3-isobutyl2-methoxypyrazine concentrations in red winegrapes. American Journal of Enology and Viticulture, v.61, p.358-364, 2010.

SILVA, L.C. da; KRETZSCHMAR, A.A.; RUFATO, L.; BRIGHENTI, A.F.; SCHLEMPER, C. Níveis de produção em vinhedos de altitude da cv. Malbec e seus efeitos sobre os compostos fenólicos. Revista Brasileira de Fruticultura, v.30, p.675-680, 2008. DOI: 10.1590/S0100-29452008000300019.

SINGLETON, V.L.; ROSSI, J.A. Colorimetry of total phenolics with phosphomolybdic-phosphotungstic acids reagents. American Journal of Enology and Viticulture, v.16, p.144-158, 1965.

SOLOS do Estado de Santa Catarina. Rio de Janeiro: Embrapa Solos, 2004. 726p. (Embrapa Solos. Boletim de pesquisa e desenvolvimento, 46)

STERNAD LEMUT, M.; TROST, K.; SILVILLOTTI, P.; ARAPITSAS, P.; VRHOVSEK, U. Early versus late leaf removal strategies for Pinot Noir (Vitis vinifera L.): effect on colour-related phenolics in young wines following alcoholic fermentation. Journal of the Science of Food and Agriculture, v.93, p.36703681, 2013. DOI: 10.1002/jsfa.6193.

SUN, Q.; SACKS, G.L.; LERCH, S.D.; VANDEN HEUVEL, J.E. Impact of shoot and cluster thinning on yield, fruit composition, and wine quality of Corot noir. American Journal of Enology and Viticulture, v.63, p.49-56, 2012. DOI: 10.5344/ajev.2011.11029.

TARDAGUILA, J.; TODA, F.M.; PONI, S.; DIAGO, M.P. Impact of early leaf removal on yield and fruit and wine composition of Vitis vinifera L. Graciano and Carignan. American Journal of Enology and Viticulture, v.61, p.372-381, 2010.

TONIETTO, J.; CARBONNEAU, A. A multicriteria climatic classification system for grape-growing regions worldwide. Agricultural and Forest Meteorology, v.124, p.81-97, 2004. DOI: 10.1016/j.agrformet.2003.06.001.

VIANNA, L.F.; MASSIGNAN, A.M.; PANDOLFO, C.; DORTZBACH, D.; VIEIRA, V.F. Caracterização agronômica e edafoclimática dos vinhedos de elevada altitude. Revista de Ciências Agroveterinárias, v.15, p.215-226, 2016. DOI: $10.5965 / 223811711532016215$.

Received on December 8, 2016 and accepted on March 2, 2017 